\title{
Survival of a marine ammonium oxidizer under energy-source deprivation*
}

\author{
Ronald D. Jones** \& Richard Y. Morita \\ Department of Microbiology and School of Oceanography, Oregon State University, Corvallis, Oregon 97331-3804, USA
}

\begin{abstract}
Cells of Nitrosomonas sp. 4W30, a chemolithotrophic ammonium oxidizing bacterium isolated from Alaskan waters, were starved for up to $25 \mathrm{wk}$ in an ammonium-free medium. Cultures were exposed to laboratory air, to $\mathrm{CO}, \mathrm{CH}_{4}$, and $\mathrm{NH}_{3}$-free air, to $50 \mathrm{nM} \mathrm{CH}$ in scrubbed air, and to $50 \mathrm{nM} \mathrm{CO}$ in scrubbed air during the period of energy-source deprivation. Cell numbers neither increased nor decreased with time of starvation, and cell size remained constant. Cultures exposed to laboratory air maintained viability over the experimental period while cells in the other treatments lost some viability. Significant numbers of cells survived the starvation period under all treatments. Despite the organisms' ability to oxidize $\mathrm{CH}_{4}$ and $\mathrm{CO}$, neither substrate increased survivability. Endogenous respiration dropped to an undetectable level by $4 \mathrm{wk}$ starvation. Results suggest that Nitrosomonas $\mathrm{sp}$. $4 \mathrm{~W} 30$ is well adapted to surviving periods of energy-source deprivation, similar to those found in the open ocean.
\end{abstract}

\section{INTRODUCTION}

Due to the nature of the system, bacteria which inhabit the open ocean often encounter periods of extreme energy-deprivation. These organisms need to be able to survive such periods of starvation. The literature dealing with starvation survival processes of heterotrophic marine microorganisms continues to grow. While much has been learned concerning the mechanisms of survival of such organisms as ANT-300 (a marine psychrophilic heterotrophic vibrio) (Novitsky \& Morita 1977, Morita 1982, Amy et al. 1983), practically nothing is known about the survival processes in chemolithotrophic organisms such as the ammonium oxidizers. Our understanding of the ecological importance of these organisms in the marine environment continues to grow as new studies indicate their role in vertical transport and nitrogen and carbon cycling (Karl et al. 1984). The availability of substrate $\left(\mathrm{NH}_{4}^{+}\right)$for these organisms is extremely limited in most of the open ocean, and it would seem likely that chemolithotrophic ammonium oxidizers must have a mechanism of survival for these periods of

\footnotetext{
- Published as Technical Paper No. 7642, Oregon Agricultural Experiment Station, USA

- Present address: Department of Biological Sciences, Florida International University, Miami, Florida 33199, USA

energy source deprivation. This study investigates the ability of a marine ammonium oxidizer, Nitrosomonas sp. $4 \mathrm{~W} 30$, to survive periods of substrate deprivation and examines the effects of its ability to utilize the trace gases, $\mathrm{CH}_{4}$ and $\mathrm{CO}$, on viability and growth of $\mathrm{NH}_{4}^{+}$starved cultures.

\section{MATERIALS AND METHODS}

Organism and cultural methods. The marine ammonium oxidizing bacterium tentatively called Nitrosomonas sp. 4W30, isolated from Alaskan coastal waters, was used for this study. A more complete description of this organism can be found in Jones \& Morita (1985). Cells for starvation survival studies were grown in a $4 \mathrm{l}$ batch culture unit equipped with an automatic $\mathrm{pH}$ controller which maintained the $\mathrm{pH}$ at $7.8 \pm 0.05$ by addition of $5 \% \mathrm{~K}_{2} \mathrm{CO}_{3}$. The medium used was the same as described by Jones \& Hood (1980) with the salinity adjusted to $30 \%$ using Instant Ocean Synthetic Sea Salts (Aquarium Systems, Inc.). Cultures were vigorously aerated and agitated by a magnetic stirring bar. The batch culture unit was maintained at $5^{\circ} \mathrm{C}$ and cells used to inoculate the unit were adapted to growth at $5^{\circ} \mathrm{C}$ as previously described (Jones \& Morita 1985). Cells were grown in this unit until all of the ammonium was utilized (Nessler's rea- 
gent). Cells were then harvested by centrifugation $\left(5860 \times \mathrm{G} ; 10 \mathrm{~min} ; 5^{\circ} \mathrm{C}\right)$, washed 3 times with $\mathrm{NH}_{4}^{+}$free medium and resuspended to a density of approximately $6 \times 10^{6} \mathrm{ml}^{-1}$ in the starvation menstruum. The starvation menstruum consisted of $32 \%$ Instant Ocean which had been rendered $\mathrm{NH}_{4}^{+}$-free by boiling for 30 min at $\mathrm{pH} 11.5\left(1 \mathrm{ml} \mathrm{l}^{-1} 10 \mathrm{~N} \mathrm{NaOH}\right)$. The medium was then acidified and buffered to $\mathrm{pH} 7.8$ by the addition of $4 \mathrm{~g} \mathrm{l}^{-1}$ of N-2-Hydroxyethylpiperazine-N-2ethane sulfonic acid (HEPES) and $5 \% \mathrm{~K}_{2} \mathrm{CO}_{3}$ solution. Sterilization of the medium was accomplished by filtration through a $0.22 \mu \mathrm{m}$ membrane filter (Millipore Corp.).

Starvation conditions. The starvation survival studies were divided into 2 phases. During the first preliminary phase, cells were starved in $4 \mathrm{l}$ bottles open to the atmosphere through a sterile foam plug. Cells were starved at $5^{\circ} \mathrm{C}$ on an orbital shaker (New Brunswick Psychrotherm). This initial study allowed the determination of a sampling schedule for further experimentation and indicated, by the increase in $\mathrm{NO}_{2}^{-}$in the starvation menstruum, that $\mathrm{NH}_{3}$ in the laboratory air could be acting as an energy source for the organism. Since ammonium contamination from laboratory air can be extreme, an additional set of 41 bottles was set up in which the air in the headspace was carefully formulated. Cells were exposed to atmospheres of air scrubbed of $\mathrm{NH}_{3}, \mathrm{CH}_{4}$ and $\mathrm{CO}$, scrubbed air with the addition of $50 \mathrm{nM} \mathrm{CH}_{4}$, and scrubbed air with the addition of $50 \mathrm{nM} \mathrm{CO}$. Hopkalite and Molecular Sieve $5 \mathrm{~A}$ were employed to scrub the air. Air in the headspace was changed weekly for the duration of the starvation experiments by flushing the headspace with a stream of the appropriate mixture for $15 \mathrm{~min}$.

Parameters examined with respect to starvation time. Direct counts and optical density. Direct counts were made using a Petroff-Hauser counting chamber, and OD determinations were made using a Bausch and Lomb Spectronic 710 at $600 \mathrm{~nm}$ with a light path of $1 \mathrm{~cm}$. Cell size was determined at the same time as the direct counts using a calibrated ocular micrometer. To determine the fraction of respiring cells, a modification of the iodonitrotetrazolium violet (INT) method of Zimmermann et al. (1978) was used. Starved cells $(10 \mathrm{ml})$ were placed in a $15 \mathrm{ml}$ centrifuge tube to which $1 \mathrm{ml}$ of $2 \%$ INT was added, shaken and incubated at $10^{\circ} \mathrm{C}$ for $12 \mathrm{~h}$. This incubated suspension was concentrated by centrifugation and observed using phase-contrast microscopy. The percentage of respiring cells (those with refractile granules of INT-formazan) was determined from these cells.

Ammonium oxidation. The ability of the starved cultures to oxidize $10 \mathrm{mg} \mathrm{l}^{-1}$ of $\mathrm{NH}_{4}^{+}-\mathrm{N}$ was determined. For this assay, $25 \mathrm{ml}$ of starved cells was dispensed into each of three $60 \mathrm{ml}$ serum bottles and $10 \mathrm{mg} \mathrm{l}^{-1}$ of
$\mathrm{NH}_{4}^{+}-\mathrm{N}$ as $\left(\mathrm{NH}_{4}\right)_{2} \mathrm{SO}_{4}$ was added. The bottles were then incubated at $10^{\circ} \mathrm{C}$ for $24 \mathrm{~h}$ on an orbital shaker at $100 \mathrm{rpm}$. The bottles were then examined for nitrite production (Bendschneider \& Robinson 1952).

${ }^{14} \mathrm{CH}_{4}$ and ${ }^{14} \mathrm{CO}$ oxidation rates. Cultures of starved bacteria were examined for their ability to oxidize $\mathrm{CH}_{4}$ and $\mathrm{CO}$. For these determinations the methods of Jones \& Morita $(1983 \mathrm{a}, \mathrm{b})$ were used. $\mathrm{CH}_{4}$ assay bottles were incubated for $48 \mathrm{~h}$ at $10^{\circ} \mathrm{C}$ on an orbital shaker while $\mathrm{CO}$ assay bottles were incubated for $24 \mathrm{~h}$. Assay bottles contained $25 \mathrm{ml}$ of the starvation cultures and were prepared in triplicate.

Endogenous respiration. Before starvation, cells were grown in the batch culture unit in the presence of $150 \mu \mathrm{Ci}$ of $\mathrm{NaH}^{14} \mathrm{CO}_{3}$ (Amersham Corp; specific activity $58 \mathrm{mCi}$ mmole $^{-1} ; 0.042 \mu \mathrm{Ci} \mathrm{ml}{ }^{-1}$ ). The $\mathrm{pH}$ was controlled in the culture unit using $1 \% \mathrm{NaOH}$ to avoid dilution of the label with cold carbonate. Cells were grown, harvested and resuspended in starvation menstruum as before. The atmosphere in the headspace was scrubbed air with no additions. At various times during the starvation period, portions were removed and used to determine the endogenous respiration rate (Novitsky \& Morita 1977). The rate of endogenous respiration was calculated as the quantity of ${ }^{14} \mathrm{CO}_{2}$ evolved per day and expressed as a percentage of the total cellular carbon.

Ammonium concentration on ammonium oxidation. Effects of ammonium concentration on ammonium oxidation was examined with respect to starvation time. For this experiment, cells starved with a headspace consisting of scrubbed air were dispensed into a series of serum bottles ( $25 \mathrm{ml}$ per $60 \mathrm{ml}$ bottle) and $\mathrm{NH}_{4}^{+}-\mathrm{N}$ as $\left(\mathrm{NH}_{4}\right)_{2} \mathrm{SO}_{4}$ was added to give concentrations between 0.1 and $1.0 \mathrm{mg} \mathrm{l}^{-1}$. Bottles were incubated for $6 \mathrm{~h}$ at $10^{\circ} \mathrm{C}$ and nitrite production was assayed as before.

\section{RESULTS AND DISCUSSION}

Preliminary experiments with Nitrosomonas sp. 4W30 starved under a freely exchanging headspace of laboratory air showed that direct counts were constant and viability, as determined by the MPN technique, remained essentially constant (Fig. 1). Optical density and cell size also remained constant with starvation time. The percentage of respiring cells (INT) showed that $99 \%$ of the cells formed formazan granules at $\mathrm{T}=0$, less than $1 \%$ formed granules by Day 2 of starvation and after $4 \mathrm{~d}$ no formazan granules were observed. The ability of the cells to oxidize ammonium also decreased with starvation time, however significant activity remained throughout the starvation period. These preliminary ammonium oxidation experiments revealed a steadily increasing background of 


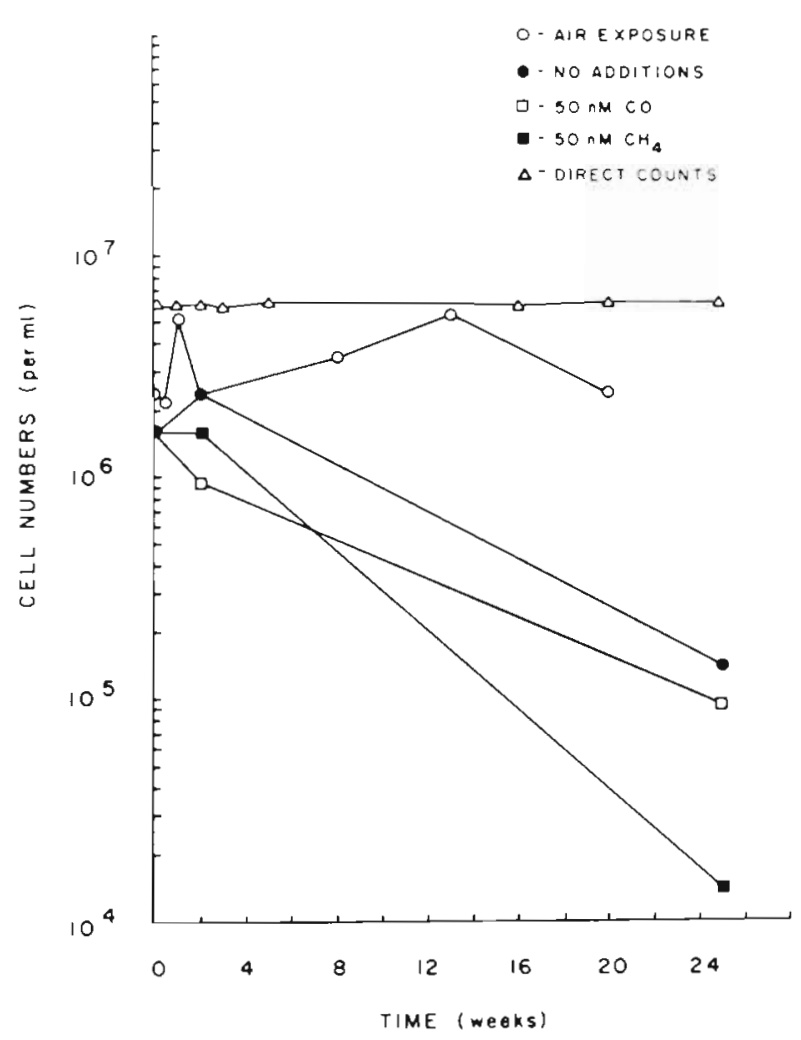

Fig. 1. Nitrosomonas sp. 4W30. Direct counts and MPN viability counts of starved cultures

$\mathrm{NO}_{2}^{-}$in the starvation menstruum $(20 \mu \mathrm{M}$ by Week 20$)$. This indicated that the organisms were oxidizing $\mathrm{NH}_{3}$ scavenged from the atmosphere. It has been demonstrated that non-nitrogen fixing marine bacteria are capable of scavenging $\mathrm{NH}_{3}$ from the air to fulfill their nitrogen requirements (Jones \& Rhodes-Roberts 1980). Since $\mathrm{NH}_{3}$ is both an energy and nitrogen source for ammonium oxidizers, the presence of atmospheric $\mathrm{NH}_{3}$ was likely to be able to provide an energy of maintenance for these organisms, thus placing doubt on the results of these preliminary experiments. This ammonia scavenging capability is likely the reason ammonium oxidizing bacteria remain viable in the laboratory for long periods of time. It has also been demonstrated that ammonium oxidizers have the ability to oxidize $\mathrm{CH}_{4}$ and $\mathrm{CO}$ (Jones \& Morita 1983a, b). Since these compounds are also present in the normal atmosphere it could be assumed that they too could serve as an energy source for starving cultures of Nitrosomonas sp. 4W30. To examine these factors, 3 additional starvation bottles were set up with the aforementioned headspace compositions.

The results of the direct counts and MPN determinations performed on these treatments are shown in Fig. 1. As in the preliminary experiment, the direct counts indicated a constant number of cells per $\mathrm{ml}$ in all 3 treatments. Viable cells as determined MPN val- ues showed that, unlike before, all of the starvation cultures lost some viability with starvation time. These experiments demonstrated that neither $\mathrm{CH}_{4}$ nor $\mathrm{CO}$ could increase survival rate of this ammonium oxidizer. It appeared that the presence of a $50 \mathrm{nM} \mathrm{CH}_{4}$ atmosphere decreased the viability of the culture. These results indicated that after $25 \mathrm{wk}$ of starvation, a significant number of cells remained viable (1 to $10 \%$ ). It is likely that these numbers are much lower than the actual viable cell count since MPN tests tend to underestimate these values. Clumping of the cells also played a role in lowering these values. In the preliminary experiment no clumping was observed, however, in experiments using the scrubbed and amended air, cells in all 3 treatments clumped, thus making MPN determinations difficult. Cell size as before did not decrease with starvation time in any of the treatments. This is an unusual finding as the miniaturization of cells appears to be a near universal phenomenon during starvation. Optical density values were also constant with starvation time, as expected since neither the cell size nor direct counts showed a change. The results of the percent respiring cells (INT) determinations were identical to those reported for the preliminary experiment.

The ability of cells to oxidize $\mathrm{NH}_{4}^{+}, \mathrm{CH}_{4}$ and $\mathrm{CO}$ decreased with starvation time in all 3 treatments (Fig. 2, $3 \& 4$ ). The ability to oxidize $\mathrm{NH}_{4}^{+}$decreased less rapidly than $\mathrm{CO}$ oxidation which decreased less

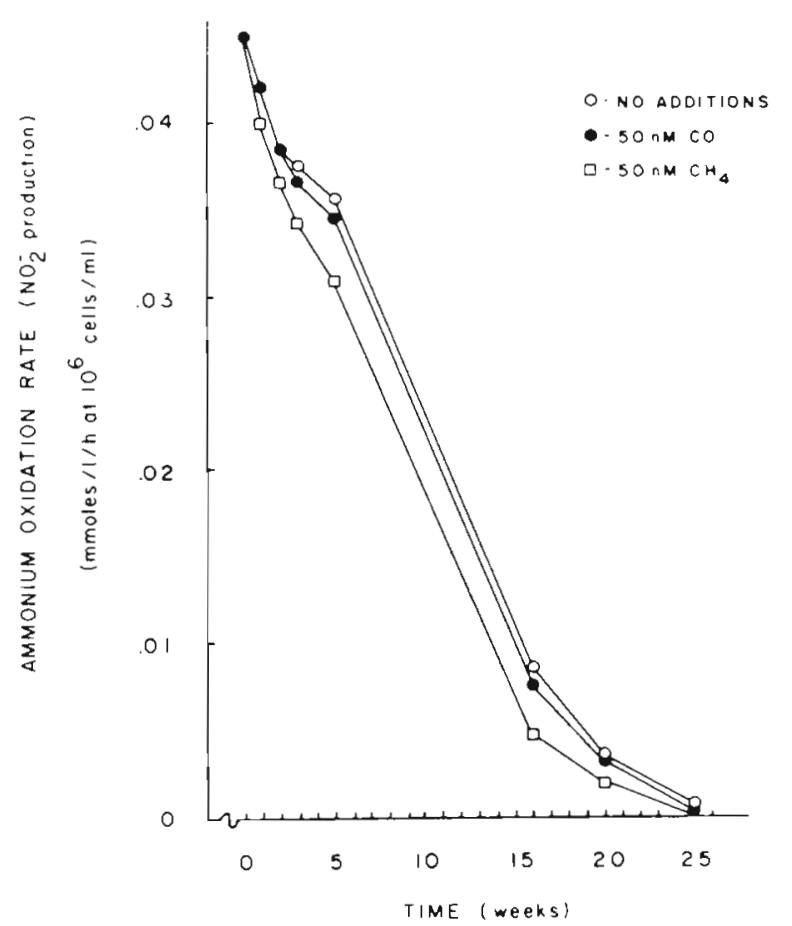

Fig. 2. Nitrosomonas sp. 4W30. Ammonium oxidation by starved cultures 


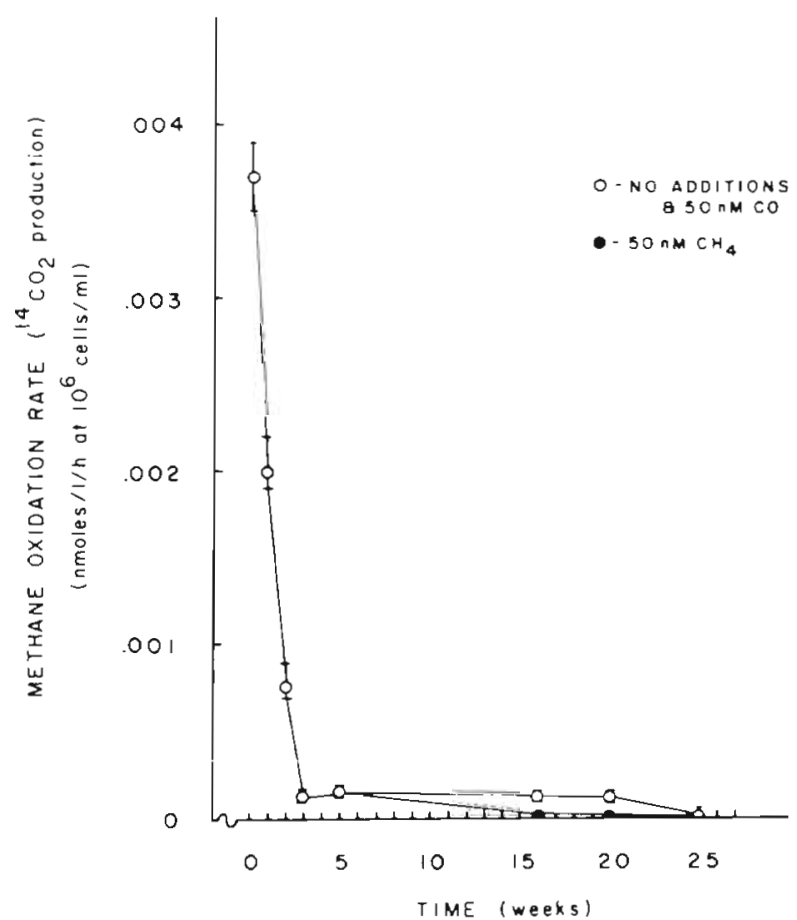

Fig. 3. Nitrosomonas sp. 4W30. Methane oxidation by starved cultures

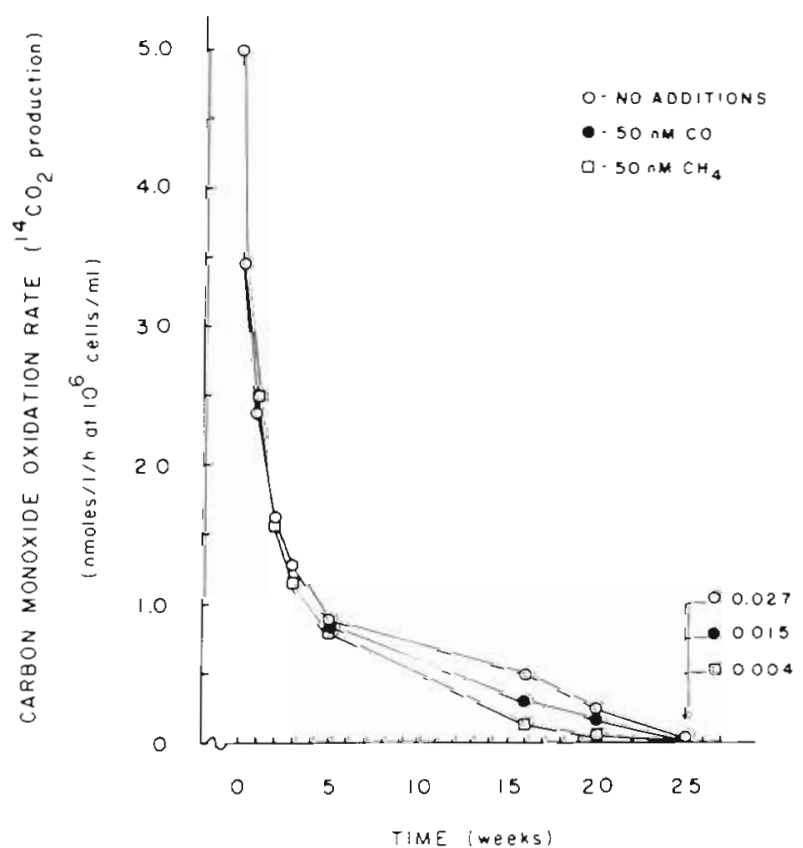

Fig. 4. Nitrosomonas sp. 4W30. Carbon monoxide oxidation by starved cultures

rapidly than $\mathrm{CH}_{4}$ oxidation. With the exception of $\mathrm{CH}_{4}$ significant oxidation occurred even at the end of $25 \mathrm{wk}$ of starvation. As with cell viability, $\mathrm{CH}_{4}$ exposure resulted in cells with a lower capacity to oxidize all 3 substrates. It is possible that this is due to the build up of incomplete oxidation products such as methanol and formaldehyde in the starvation menstruum. No tests were made to determine this, however. Again, these experiments demonstrated that despite the ability of Nitrosomonas sp. $4 \mathrm{~W} 30$ to oxidize $\mathrm{CH}_{4}$ and $\mathrm{CO}$, these substrates do not increase the ability of the organism to survive $\mathrm{NH}_{4}^{+}$deprivation.

Results of the endogenous respiration experiments are given in Fig. 5. The ability to decrease endogenous metabolism and conserve cellular carbon during energy source deprivation has obvious advantages. Nitrosomonas sp. 4W30 rapidly decreases its endogenous respiration from $2 \% \mathrm{~d}^{-1}$ to $0.00 \%$ after $4 \mathrm{wk}$ of starvation. Novitsky \& Morita (1977) reported that ANT-300 reduced its endogenous respiration by over $99 \%$ during the first week of starvation, after which the rate remained constant at $0.0071 \% \mathrm{~h}^{-1}$, and similar results have been reported by Kurath \& Morita (1983) for a Pseudomonas sp. Novitsky \& Morita (1977) report that cells respire $50 \%$ of their organic carbon by the end of $5 \mathrm{wk}$ of starvation. With Nitrosomonas sp. 4 W30 only $6.7 \%$ of the cellular carbon was respired by $4 \mathrm{wk}$ and no detectable additional loss was observed after this period. This correlates well with the finding that cell size remained constant upon starvation. This ability to conserve cellular carbon is likely to be an important factor in the survival of ammonium oxidizers.

The ability of starved cells to respond to increasing concentrations of $\mathrm{NH}_{4}^{+}$are shown in Fig. 6. These

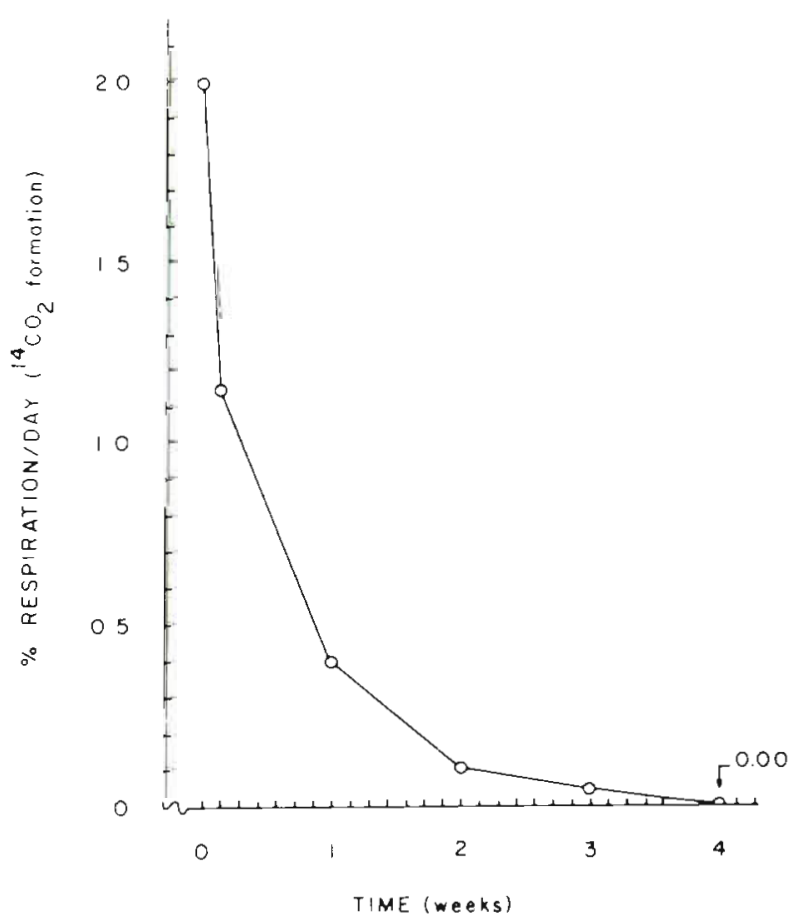

Fig. 5. Nitrosomonas sp. 4W30. Endogenous respiration of starved cultures 


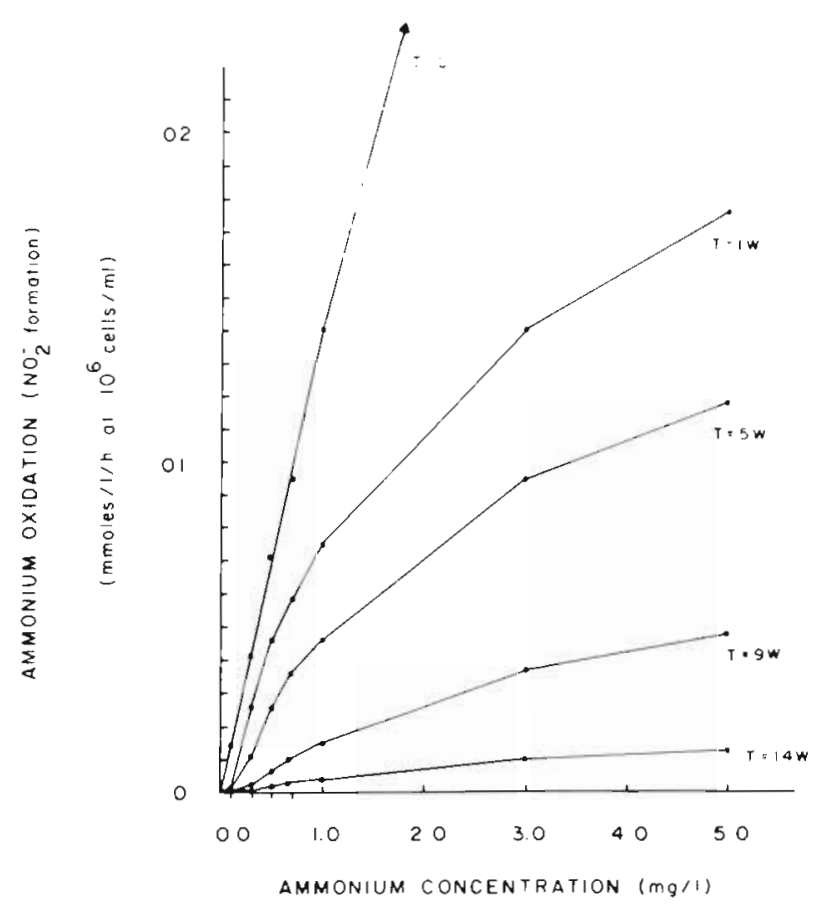

Fig. 6. Nitrosomonas sp. 4W30. Effects of ammonium concentration on ammonium oxidation by starved cultures

experiments revealed several points concerning the enzyme-substrate kinetics of ammonium oxidizers. It can be seen from Fig. 6 that while unstarved cells $(\mathrm{T}=0)$ behave as expected for $1^{\text {st }}$ order kinetics, after only $1 \mathrm{wk}$ of starvation, the initial lag in response to increasing $\mathrm{NH}_{4}^{+}$concentration does not fit the definition of $1^{\text {st }}$ order kinetics. It is possible that this initial lag in increasing activity is due to the cells' need to regenerate the reducing potential (possibly $\mathrm{NADH}$ ) from ATP, to initiate the initial oxidation of $\mathrm{NH}_{4}^{+}$to $\mathrm{NH}_{2} \mathrm{OH}$. The observed decrease in the ability of the starved cells to respond to increase in $\mathrm{NH}_{4}^{+}$concentration increased with time. This finding should be considered when examining the kinetics and substrate responses of natural populations of ammonium oxidizers. Olson (1981) reported that natural populations of ammonium oxidizers show very little response to increasing ammonium concentration. Results of these experiments suggest that his observations may be due to the physiological state of the cells rather than to kinetics $(\mathrm{Km})$ of the ammonium monooxygenase system.

The ability of chemolithotrophic ammonium oxidizers to survive energy source deprivation could be an important factor in the cycling of nitrogen and carbon in the marine environment. These experiments demonstrate that at least one ammonium oxidizer, Nitrosomonas sp. $4 \mathrm{~W} 30$, has the ability to survive periods of energy source deprivation, and experiments in our laboratory have shown that Nitrosococcus oceanus, Nitrosomonas europaea and an estuarine isolate from Florida have similar patterns of survival (Jones \& Morita unpubl.).

Acknowledgements. We thank Liz Jones for preparing the figures. This paper is based on research supported by National Science Foundation grant OCE81-8366. Hopkalite, employed in this investigation, was a gift from Drägerwerk A. G., Lübeck, Federal Republic of Germany.

\section{LITERATURE CITED}

Amy, P. A., Pauling, C., Morita, R. Y. (1983). Recovery from nutrient starvation by a marine Vibrio sp. Appl. environ. Microbiol. 45: 1685-1690

Bendschneider, K., Robinson, R. J. (1952). A new spectrophotometric method for the determination of nitrite in sea water. J. mar. Res. 11: 87-96

Jones, K. L., Rhodes-Roberts, M. E. (1980). Physiological properties of nitrogen-scavenging bacteria from the marine environment. J. appl. Bacteriol. 49: 421-433

Jones, R. D. Hood, M. A. (1980). The effects of temperature, $\mathrm{pH}$, salinity and inorganic nitrogen on the rate of ammonium oxidation by nitrifiers isolated from wetland environments. Microb. Ecol. 6: 339-347

Jones, R. D., Morita, R. Y. (1983a). Carbon monoxide oxidation by chemolithotrophic ammonium oxidizers. Can. J. Microbiol. 29: 1545-1551

Jones, R. D., Morita, R. Y. (1983b). Methane oxidation by Nitrosococcus oceanus and Nitrosomonas europaea. Appl. environ. Microbiol. 45: 401-410

Jones, R. D., Morita, R. Y. (1985). Low-temperature growth and whole-cell kinetics of a marine ammonium oxidizer. Mar Ecol. Prog. Ser. 21: 239-243

Karl, D. M., Knauer, G. A., Marine, J. H., Ward, B. B. (1984). Bacterial chemolithotrophy in the ocean is associated with sinking particles. Nature, Lond. 309: 54-56

Kurath, G., Morita, R. Y. (1983). Starvation-survival physiological studies of a marine Pseudomonas sp. Appl. environ. Microbiol. 45: 1206-1211

Morita, R. Y. (1982). Starvation-survival of heterotrophs in the marine environment. Adv. microb. Ecol. 6: 171-198

Novitsky, J. A., Morita, R. Y. (1977). Survival of a psychrophilic marine vibrio under long-term nutrient starvation. Appl. environ. Microbiol. 33: 635-641

Olson, R. J. (1981). ${ }^{15} \mathrm{~N}$ tracer studies of the primary nitrite maximum. J. mar. Res. 39: 203-226

Zimmermann, R., Iturriaga, R., Becker-Birck, J. (1978). Simultaneous determination of the total number of aquatic bacteria and the total number thereof involved in respiration. Appl. environ. Microbiol. 36: 926-935 